\title{
Annals of Dyslexia New Investigator Award
}

Published online: 14 February 2019

(C) The International Dyslexia Association 2019

We invite graduate students, postdoctoral fellows, and early career investigators (first 5 years of career) who have published their research in Annals of Dyslexia in 2018 to apply for the Annals of Dyslexia New Investigator Award. This award is made possible by a gift from Springer.

Award Amount: $\$ 500.00$

Application Deadline: June 30, 2019

The award recipient will be recognized during the annual International Dyslexia Association conference. The recipient will also be invited to present the research findings during a symposium highlighting recent findings published in Annals of Dyslexia led by the journal editors.

\section{Eligible candidates must meet the following criteria:}

1) Applicants must be graduate students (MA and Ph.D.), postdocs, research scientists, or faculty who have not received their Ph.D. more than five years ago (i.e., the applicant's $\mathrm{Ph} . \mathrm{D}$. must have been awarded no earlier than July 2014, although consideration will be given for parental or medical leaves if requested).

2) Applicants must be the first or second author of a paper published in Annals of Dyslexia within the past year (from January 1 to December 31, 2018).

\section{Please submit the following application materials:}

1) A nomination letter written by the graduate supervisor or a senior colleague. The letter should a) summarize the applicant's research, b) indicate the applicant's contribution to the published research, and c) make the case for the nominee's promise and dedication to the field of reading research.

2) A cover letter that includes the citation for the article published in Annals of Dyslexia.

3) A Curriculum Vitae

Please send your application materials to Becky Chen at xchenbumgardner@gmail.com. You are also encouraged to contact Becky to express your interest before submitting your application.

Publisher's note Springer Nature remains neutral with regard to jurisdictional claims in published maps and institutional affiliations. 